\title{
Nitrogen Fixation in Arctic Coastal Tundra in Relation to Vegetation and Micro-Relief
}

\author{
DONALD M. SCHELL and VERA ALEXANDER ${ }^{1}$
}

\begin{abstract}
A study to estimate nitrogen fixation input in arctic corstal tundra was carried out using the acetylene reduction assay. Areal estimation was attempted by high intensity sampling over a limited area of tundra containing both high-centred and lowcentred polygons with their corresponding variations in micro-vegetation. The highest average rates of acetylene reduction were obtained from cores in damp interpolygonal troughs $\left(10.50 \mu\right.$ moles ethylene/m. ${ }^{2}$-hr) where mats of the blue-green alga Nostoc were abundant. Wet moss-algal associations in hydric meadows showed high nitrogenase activity (average $6.86 \mu$ moles ethylene/m. ${ }^{2}$-hr) and dry high-centred polygons were comparatively inactive (average $2.80 \mu$ moles ethylene/m.2-hr). The lichens Peltigera sp. and Stereocaulon sp. were the most active nitrogen fixers in the drier tundra. Nitrogen fixation increased with rising temperature with a measured $\mathrm{Q}_{10}$ for Nostoc commune of 3.7.
\end{abstract}

RÉSUMÉ: Fixation de l'azote dans la toundra côtière arctique, par rapport à la végétation et au micro-relief. Les auteurs ont mené une étude pour estimer l'apport d'azote fixé dans la toundra côtière arctique, par le titrage de la réduction par l'acétylène. Ils ont tenté un estimé de surface par échantillonnage intense d'une aire limitée de toundra comprenant à la fois des polygones en dômes et des polygones en creux, avec les variations correspondantes dans la micro-végétation. Les taux moyens les plus élevés de réduction par l'acétylène ont été obtenus sur des carottes provenant de sillons interpolygonaux humides $\left(10.50 \mu\right.$ moles d'éthylène $\left./ \mathrm{m}^{2}-\mathrm{h}\right)$ où abondent les touffes de l'algue bleu-vert Nostoc. Les associations mousse-algue humides des prairies hydriques montrent une forte activité de nitrogénase (moyenne de $6.86 \mu$ moles d'éthylène $/ \mathrm{m}^{2}-\mathrm{h}$ ), et les polygones secs en dôme sont comparativement inactifs (moyenne de $2.80 \mu$ moles d'éthylène $/ \mathrm{m}^{2}-\mathrm{h}$ ). Dans la toundra plus sèche, les lichens Peltigera sp. et Stereocaulon sp. sont les fixateurs les plus actifs de l'azote. La fixation de l'azote augmente avec la température, le $Q_{10}$ mesuré pour Nostoc commune étant de 3.7.

РЕЗЮМЕ. Сявзь фиксаџии азота в арктической березовой тундре с растительностью и микрорелъефом. Проведена оценка количества фиксируемого азота в арктической береговой тундре по степени уменьшения ацетилена. Региональная оценка сделана на основе подробного изучения опытных участков тундры, содержащих как высокодентрированные, так и низкоцентрированные полигоны с соответствующими различиями микрорастительности. Наиболее высокие средние скорости уменыенця ацетилена были получены в пробах из влазных впадин между полигонами (10.50 мкмолей этилена/м²-час), содержащих в болышом количестве сине-зелёные водоросли Nostoc. Влажные сообщества мха и водоролей на лугах обнаружили высокую азотную активность (в среднем 6.86 мкмолей этилена/м²-час), а сухие высокодентрированные полигоны были сравнительно малоактивны (в среднем 2.80 мкмолей әтилена/ $\mathrm{m}^{2}-$ час). Литайники видов Peltigera и Stereocaulon оказались наиоблее активными фиксаторами азота в более сухих участках тундры. Фиксация азота увеличивалась с ростом температуры. Согласно проведенным измерениям, величина $\mathrm{Q}_{10}$ для Nostoc commune составляла 3.7.

IInstitute of Marine Sciences, University of Alaska, Fairbanks, U.S.A. 


\section{INTRODUCTION}

Nitrogen fixation is one of the most important biological processes in that it plays a vital role in maintaining the productivity of the biosphere. Although considerable impetus has been given to studies of nitrogen fixation by the development of highly efficient methods of detection, the tundra ecosystem has remained essentially unexamined in this respect until the present time. Antarctic lichens and the blue-green algae Nostoc commune have been shown by Fogg and Stewart (1968) to fix nitrogen, and the importance of Nostoc sp. as nitrogen fixers either by themselves or as phycobionts in lichens has been emphasized. Further studies on the lichens Collema tuniforme and Peltigera rufescens by Henriksson and Simu (1971) revealed the ability of lichens to recover nitrogen-fixing capacity rapidly after periods of desiccation. The presence of free-living blue-green algae in many arctic and subarctic Swedish soils (Granhall and Henriksson 1969) and their ability to attach to the surfaces of growing plants further emphasizes the potential of these algae to contribute directly the nitrogen input in complex plant communities.

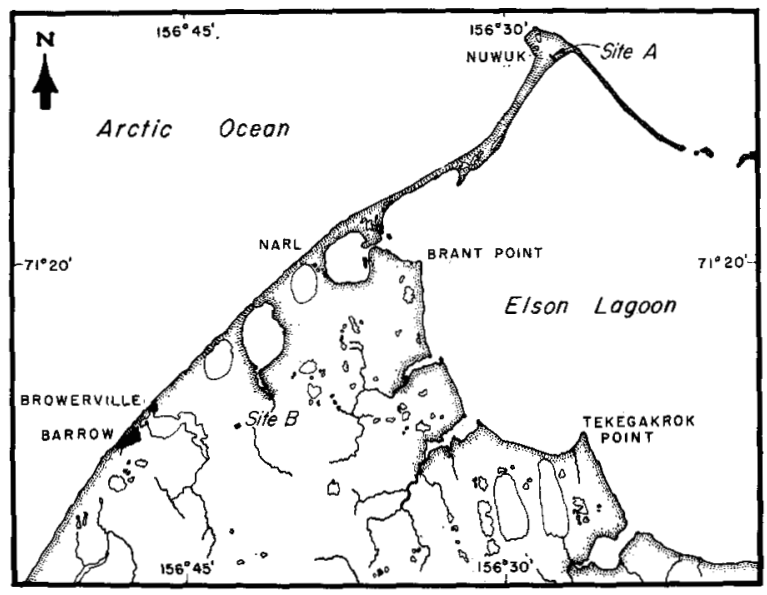

FIG. 1. Map of the Barrow area, Alaska, showing the two research sites (A and $B$ ).

This work presents the results of a study to measure the nitrogen fixation input to an arctic coastal tundra ecosystem. As part of the Tundra Biome, U.S. International Biological Program (IBP), we have been investigating nitrogen fixation in arctic and alpine tundra. In particular, the relationships between nitrogen fixation rates and the microrelief of coastal tundra and associated vegetation types have been studied. This was essentia because, within the Barrow vicinity, nitrogen fixation turned out to be highly variable between adjacent samples. An approach to areal estimation was therefore designed, and the results of this particular phase of the overall program are discussed here.

The sites chosen for intensive study were located near Point Barrow, Alaska (Fig. 1). During the summer months, the prevailing arctic maritime climate is typified by near-freezing temperatures with short exceptions during clear days when temperatures may reach $20^{\circ} \mathrm{C}$. Daylight is continuous from early May until early August. Vegetation reflects the extreme climate and consists of decumbent 


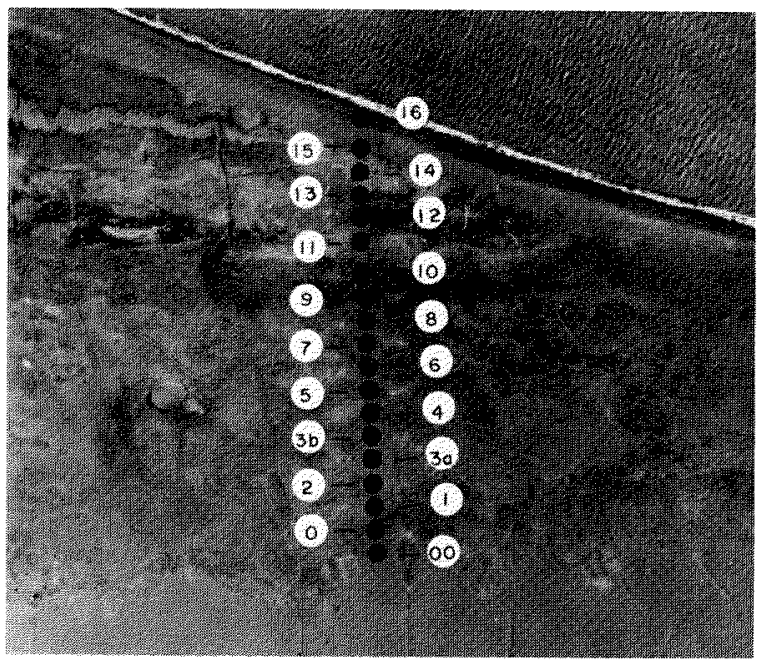

FIG. 2. Nuwuk nitrogen

fixation transect showing experimental stations.

Salix species with grasses and sedges $20 \mathrm{~cm}$. high typifying the tallest plants. The low-centred polygon ponds and the interpolygonal pools of over $20 \mathrm{~cm}$. depth were either devoid of emergent plants or occasionally contained Ranunculus pallasii. Little benthic flora was evident in open ponds and although some algal populations were noted, the density nowhere approached that found in polygonal troughs.

\section{METHODS}

The first location chosen to test the feasibility of areal estimation of nitrogen fixation rates was at Nuwuk on the sparsely vegetated sandspit north of Barrow (Fig. 1). Site selection was made from an aerial photograph and a transect laid out with sampling points at $10 \mathrm{~m}$. intervals (Fig. 2). The first point near the crest of the spit was in gravel and the final point at the beach was also in gravel. The vegetation on the slope between the beach and crest ranged from lichen crusts at the upper edge through grassy bogs to submerged grasses coated with attached algae near the beach. Mats of Nostoc were present in the wetter areas except near the beach.

For a detailed study, a locality was chosen near the IBP intensive study sites 2 miles $(3.2 \mathrm{~km}$.) south of the Naval Arctic Research Laboratory. Photographic flight lines were made over the area of interest and from the photographs a site was selected which encompassed a transition zone from high-centred to lowcentred polygonal tundra. A concentric circular distribution of sampling sites was then laid out at $10 \mathrm{~m} ., 20 \mathrm{~m}$., and $30 \mathrm{~m}$. radii. Points $10 \mathrm{~m}$. apart were marked off on the $30 \mathrm{~m}$. circle and on radial intersections with the $20 \mathrm{~m}$. and $10 \mathrm{~m}$. circles. The 52 points of the plot were sampled on 24 and $28 \mathrm{July}$, and 2 August, 1971. Fig. 3 shows the location of sampling points.

Nitrogen fixation was measured by the acetylene reduction technique of Stewart et al. (1967). This technique derives from the fact that the nitrogenase enzyme responsible for nitrogen fixation is sufficiently non-specific toward 
substrate that several molecules including acetylene are accepted into the reductive template. With acetylene, reduction proceeds as far as ethylene and by measuring the rate of ethylene production, quantification of nitrogenase activity is possible. The theoretical molar ratio of ethylene-produced/nitrogen-fixed is 1.5 , but in practice depends upon the species tested and experimental conditions, having been found to vary considerably. For natural populations of blue-green algae, Stewart et al. (1968) obtained a ratio ranging from 1.4 to 1.8 , which is close to the theoretical figure mentioned above. The current assumption in the literature favours the theoretical 1.5 as the conversion factor (Stewart et al. 1971), although much of the field work is currently reported in terms of ethylene produced (see, for example, Bunt et al. 1970). The acetylene assay is so rapid and simple that, although an indirect measure, it has become the widely accepted test for nitrogen fixation, especially under field conditions. Tundra samples were taken using a $16 \mathrm{~cm} .{ }^{2}$ core punch. The moss layer was trimmed at $3 \mathrm{~cm}$. depth and the sample then placed in a $60 \mathrm{cc}$. glass vial and capped. Lichen samples were hydrated with $2.0 \mathrm{ml}$. of water. For samples of moss and vegetation in
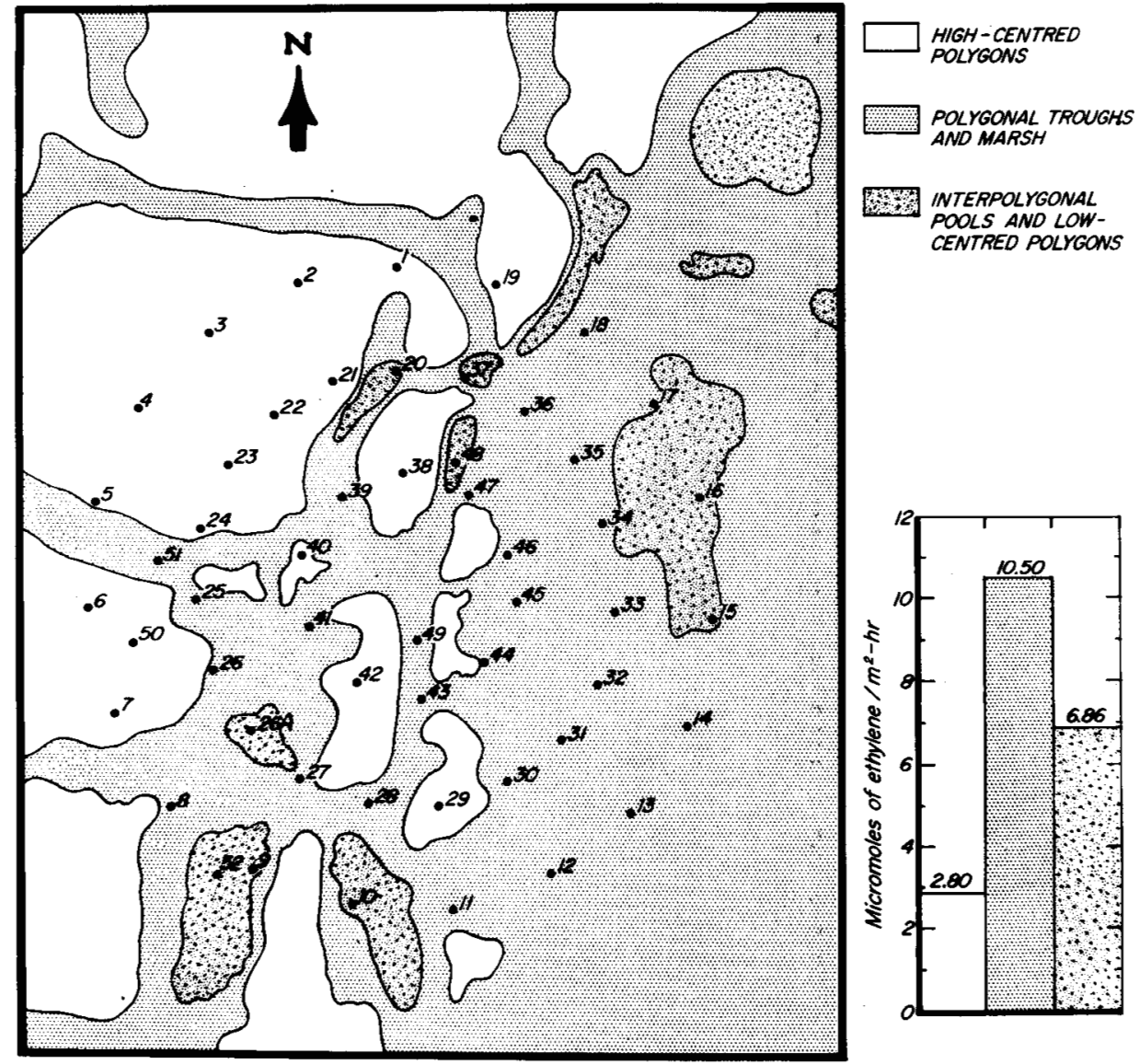

FIG. 3. The nitrogen fixation intensive site showing stations, relief and related average acetylene reduction rates. 
water a $20 \mathrm{~cm}$. clear butyrate core liner was used to punch an undisturbed sample of the bottom vegetation. The core was capped under water and removed with minimum suspension of sediment.

Upon returning to the laboratory, acetylene was injected through a hole in the vial caps or through the plastic caps of the core liners displacing 10 to 20 per cent of the air volume. As much as possible of the excess water in the core liners was decanted to insure intimate contact between the acetylene and vegetation. No attempt was made to flush the nitrogen present from the samples as previous work indicated no significant suppression of acetylene reduction by the presence of nitrogen. This has been confirmed by others (Stewart et al. 1970). Incubation was carried out in daylight with the vials submerged in a glass tray filled with water. This had the effect of preventing heating within the vials. After the desired incubation period, ranging from 6 to 24 hours, samples of the gas mixture within the vials were collected in Vacutainers ${ }^{\circledR}$ for subsequent analysis (Schell and Alexander 1970).

Determination of the ethylene produced was performed using an F \& M model 700 gas chromatograph equipped with a flame-ionization detector. A 12-foot (3.6 m.) $\times 1 / 8$ inch $(3 \mathrm{~mm}$.) diameter stainless steel column packed with Porapak R gave excellent separation of ethylene and acetylene at $40^{\circ} \mathrm{C}$. For calibration of peak heights a commercially prepared standard containing 11.9 PPM ethylene and 10,300 PPM acetylene was used. Ethylene values determined from peak heights were used with the measured volume of the incubation vessel to determine the total ethylene produced by the sample. This was then divided by the incubation time and area of the sample to get an average value of ethylene production per unit area with time.

\section{RESULTS}

The samples taken from Nuwuk site represent a single transect of that area and as such some inaccuracy due to non-representative sampling is to be expected. Nevertheless the values of nitrogen fixation shown in Fig. 4 correlate well with nitrogen-fixing algae found in the vicinity of sample sites. In the areas of marshy tundra, mats of Nostoc commune were common. The high values of nitrogen fixation next to the exposed gravel of the sandspit crest are probably due to lichens of Stereocaulon sp. and Peltigera sp. The thickness of the lichen crust is between 1 and $3 \mathrm{~cm}$. and overlaps a well-sorted and drained pea gravel

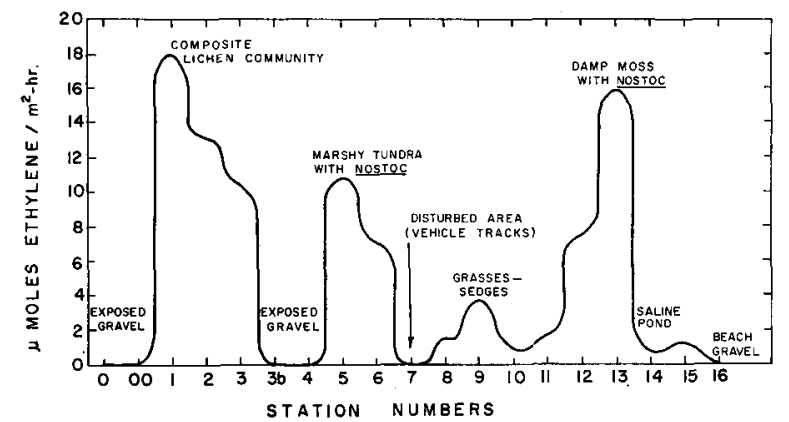

FIG. 4. Nitrogen fixation rates across Nuwuk transect. 
substratum. The nitrogen-fixing lichens at this location are probably essential to the sustenance of this pioneer community.

The more complex plant communities in the wetter areas were supported by 5 to $10 \mathrm{~cm}$. of peat soils. Although no microscopic inspection for minute colonies of blue-green algae was performed, Nostoc commune was very evident as large mats at points 5 and 13. Petasites $\mathrm{sp}$. and Carex aquatilis were present as a sparse canopy vegetation in these areas. Low values of nitrogen fixation were found at points 14 to 16 where saline water intruded over the vegetation during occasional summer storms.

The intensive study location near the IBP site gave a more coherent picture of nitrogen fixation input to the tundra community. Fig. 5 shows the average nitrogen fixation values in zones of relative elevation and dryness. The wetter areas in the polygonal troughs and marsh averaged $10.5 \mu$ moles $\mathrm{C}_{2} \mathrm{H}_{4}$ produced/ $\mathrm{m}$. ${ }^{2}$-hr. or over 3 times the value of $2.80 \mu$ moles $\mathrm{C}_{2} \mathrm{H}_{4} / \mathrm{m} .{ }^{2}$-hr. for the highcentred polygons. The areas defined as wet (under standing water) were intermediate with an average value of $6.86 \mu$ moles $\mathrm{C}_{2} \mathrm{H}_{4} / \mathrm{m} .{ }^{2}$-hr. Although the highcentred polygon areas showed an apparent increase in average fixation rates from 24 to 28 July and remained essentially the same on 2 August the wetter areas decreased markedly in nitrogen-fixation capacity during the same period. A review of Barrow weather records indicates that these responses may be in some

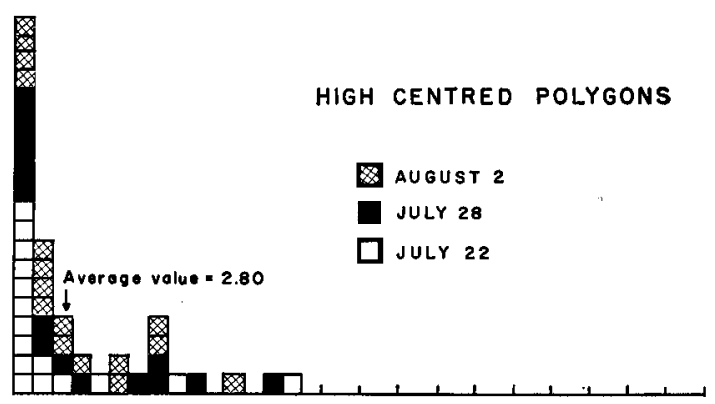
FIG. 5. Nitrogen fixation results for the intensive site.

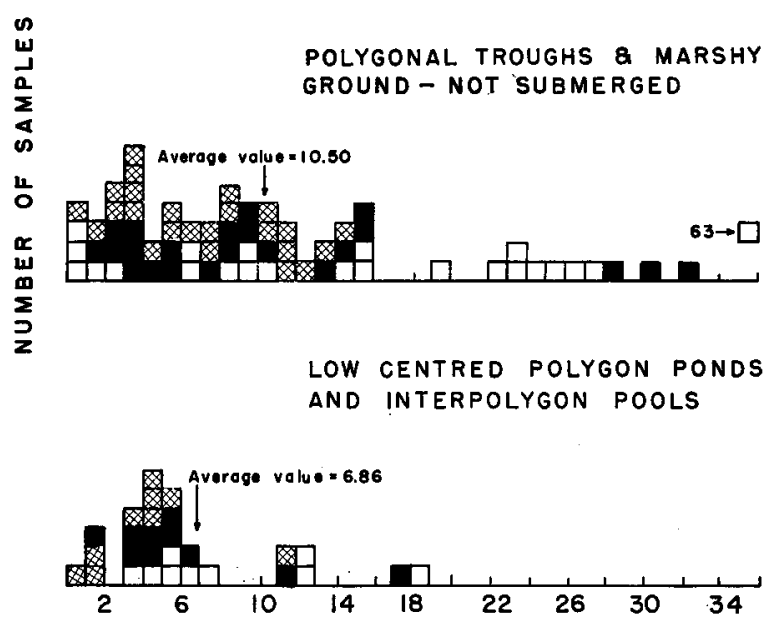

MICROMOLES ACETYLENE REDUCED $/ \mathrm{m}^{2}-\mathrm{hr}$. 
part due to weather conditions. Although the incubation vials were immersed in water, no temperature regulation was attempted, and whereas 24 July was a partly cloudy day and air temperatures ranged from $3^{\circ} \mathrm{C}$. to $7 \mathrm{C}$. during incubation, the sunshine probably raised the temperatures inside the vials considerably higher. Temperatures on 28 July were very similar but the day was solidly overcast; it was again solidly overcast on 2 August with air temperatures remaining at $+1^{\circ} \mathrm{C}$. during the incubation period. Fogg and Stewart (1968) felt that temperature was the most important factor governing nitrogen-fixation rates in antarctic blue-green algae and that most fixation occurred during periods when the air temperature in the microhabitat reached $10^{\circ} \mathrm{C}$. or more. Our data only partially support this conclusion. The increase in nitrogen-fixation rates obtained in the high-centred polygons on 24 and $28 \mathrm{July}$ are opposite to that expected if temperature was the controlling factor. The lower areas, however, gave decreasing rates which coincided with the progressively colder and overcast sampling days. Horne (1972) suggested that in the Antarctic temperature and desiccation are closely interrelated, so that the presence of liquid water is the important factor. An experiment to test the effect of light and temperature on acetylene reduction by Nostoc showed a clear increase in activity with temperature, with a $\mathrm{Q}_{10}$ of 3.7. Samples incubated in total darkness under otherwise identical conditions to samples in light did not show appreciable inhibition of nitrogenase activity after 20 hours. These data are shown in Table 1.

TABLE 1. The effect of light and temperature on acetylene reduction by Nostoc-moss association. Samples incubated for 20 hours.

\begin{tabular}{|c|c|}
\hline Incubation Conditions & ${ }_{\mu M o l e s}$ ethylene/hr.-dry wt. (mg.) \\
\hline $18^{\circ} \mathrm{C}$ light & $\begin{array}{l}0.221 \\
0.581\end{array}$ \\
\hline $18^{\circ} \mathrm{C}$ dark & $\begin{array}{l}0.347 \\
0.101\end{array}$ \\
\hline $0^{\circ} \mathrm{C}$ light & $\begin{array}{l}0.035 \\
0.044\end{array}$ \\
\hline $0^{\circ} \mathrm{C}$ dark & $\begin{array}{l}0.033 \\
0.048\end{array}$ \\
\hline
\end{tabular}

The principal groups of nitrogen-fixing organisms can be attributed to 3 habitat types with considerable overlap between them. Dry areas such as the high-centred polygons tend to have minimal free-living blue-green algae on the soil surface but fixation was instead attributable almost entirely to blue-greens present as phycobionts in Peltigera sp. and other lichens. The periodic exposure of the nearly bare polygon tops to extreme desiccation during summer is unfavourable for the growth of free-living algae and the erosive effects of windblown snow during the winter preclude the development of vegetative cover sufficient to retain moisture and provide a protective canopy.

In the polygonal troughs and marshy ground the proximity of permafrost beneath the surface of the soil retards the loss of moisture and a very damp microenvironment is maintained. In these areas, nitrogen fixation is correlated to large mats of Nostoc commune or to free-living algae intimately associated 
with the vegetation, particularly mosses. Enhancement of fixation in this zone may be stimulated by the leaching of phosphate and other nutrients from the high-centred polygons into the troughs.

Stewart et al. (1970) have found that the addition of microgram quantities of orthophosphate to phosphate-starved nitrogen-fixing algae resulted in rapid increases in nitrogen reduction. The nutrient concentrations in both soil and aquatic environments in the IBP intensive site area are extremely low. Preliminary experiments to investigate the effects of various nutrient enrichments have been performed on lichens with inconclusive results and further work is intended using Nostoc colonies and lichens.

The lowest areas including interpolygon pools were usually carpeted with mosses and supported large amounts of blue-green algae. The marshy area included in the area of points 14 to 16 was overlain with a nearly continuous cover of Drepanocladus sp. with Carex aquatilis as the canopy. Uniformly high rates at nitrogen fixation were found throughout this area and inspection of the moss revealed Nostoc associated throughout. The interpolygon pools, such as points 26A, 48 and 52, contained a continuous layer of the mosses Calliergan sp. and Minium sp. with Dupontia fischerei emergent. Nitrogen fixation was of significance in this environment again as a result of associated Nostoc sp.

\section{ACKNOWLEDGEMENTS}

This work was supported by NSF Grant No. GV 29342 to the University of Alaska (Tundra Biome, I.B.P.). The technical assistance of Cathleen Chmielowski is acknowledged with thanks. Acknowledgement is also due to the Naval Arctic Research Laboratory, Barrow, for laboratory and field support. Dr. Herbert Melchior provided valuable assistance with plant identification, and Mrs. G. B. Threlkeld gave both botanical advice and help with illustrations.

\section{REFERENCES}

BUNT, J. S., K. E. COOKSEY, M. A. HEEB, C. C. LEE and B. F. TAYLOR. 1970. Assay of algal nitrogen fixation in the marine subtropics by acetylene reduction. Nature. 227: 1163-64.

FOGG, G. E. and W. D. P. STEWART. 1968. In situ determinations of biological nitrogen fixation in Antarctica. British Antarctic Survey Bulletin, 15: 39-46.

GRANHALL, U. and E. HENRIKSSON. 1969. Nitrogen-fixing blue-green algae in Swedish soils. Oikos, 20: 175-78.

HENRIKSSON, E. and B. SIMU. 1971. Nitrogen fixation by lichens. Oikos, 22: 119-21.

HORNE, A. J. 1972. The ecology of nitrogen fixation in Signy Island, South Orkney Islands. British Antarctic Survey Bulletin, 27: 1-18.

SCHELI, D. M. and V. ALEXANDER. 1970. Improved incubation and gas sampling techniques for nitrogen fixation studies. Limnology and Oceanography, 15: 961-962.

STEWART, W. D. P., G. P. FITZGERALD and R. H. BURRIs. 1967. In situ studies on $\mathrm{N}_{2}$ fixation using the acetylene reduction technique. Proceedings of the National Academy of Science, 58: 2071-78. biologie, 62: 336-48.

1970. Acetylene reduction assay for determination of phosphorus availability in Wisconsin lakes. Proceedings of the National Academy of Science, 66: 1104-11.

STEWART, W. D. P., T. MAGUE, G. P. FITZGeral.D and B. H. BURRIS. 1971. Nitrogenase activity in Wisconsin lakes of differing degrees of eutrophication. New Phytologist, 70: 497-50. 